\title{
The use of laser biostimulation in human and animal physiotherapy - a review
}

\author{
Paulina Zielińska1 ${ }^{1}$, Maria Soroko², Anna Zwyrzykowska³ ${ }^{2}$ Zdzisław Kiełbowicz ${ }^{1}$ \\ Wroclaw University of Environmental and Life Sciences, \\ ${ }^{1}$ Faculty of Veterinary Medicine, Department of Surgery, \\ ${ }^{2}$ Faculty of Biology and Animal Science, Department of Horse Breeding and Equestrian Studies, \\ ${ }^{3}$ Department of Environment Hygiene and Animal Welfare, Wroclaw, Poland
}

Received January 25, 2016

Accepted February 17, 2017

\begin{abstract}
Laser biostimulation involves applying a laser beam to the tissue to facilitate healing and regenerative processes. Laser therapy is one of the most important physical methods used in human physiotherapy. In veterinary medicine, laser therapy is a new and so far poorly examined method. The results of studies conducted so far are very promising, yet the positive effect of laser light, especially that of class IV, has yet to be confirmed. This article presents an overview of the available literature on the effect of laser treatment on the human and animal organism.
\end{abstract}

Low level laser therapy (LLLT), high intensity laser therapy (HILT), physical therapy

The history of laser radiation goes back to 1917 when Albert Einstein discovered the phenomenon of stimulated emission (Riegiel and Sephion 2007). Since then, there have been efforts to create a device emitting laser radiation. In 1960 at Hughes Research Laboratories in Malibu, Theodor Mainman made the first active laser with a wavelength of $693.3 \mathrm{~nm}$ (Glinkowski and Pokora 1995), which paved the way for rapid development in this area. The term LASER is an acronym of "light amplification by stimulated emission of radiation". The most important features of laser include monochromatism, collimation, and coherence of a beam. As a result, it can deliver large amounts of energy to a welldefined place in a short time (Kitchen and Partridge 1991).

Currently, laser light is used in almost all areas of medicine. The effects of tissue photodestruction and photocoagulation are used in surgery as they enable precise incision with limited bleeding during surgery. In oncology, laser light is used for photodynamic therapy and photodynamic diagnosis of tumours. In physiotherapy, laser photobiostimulation is carried out to accelerate the regenerative processes in damaged tissue (Fiodor et al. 1995; Mikołajewska 2011).

Photobiostimulation has anti-inflammatory, analgesic, antioedema and regenerative effects. It causes an increase in cell metabolism, changes in the structure and function of biological membranes, increased enzyme activity and the release of endorphins, vasodilation and angiogenesis, and increased reproductiveness and activity of immune cells (Riegiel and Sephion 2007).

Until recently, treatment with class IIIB lasers with a power not exceeding $500 \mathrm{~mW}$, also called low-level laser therapy (LLLT), was used. This type of laser therapy does not increase the temperature of irradiated tissue above $1^{\circ} \mathrm{C}$ (Ward et al. 2009). The development of new technologies in recent years has allowed for the invention of therapeutic laser devices with a much higher power (class IV lasers), which are currently applied not only in surgery but also in laser therapy (high intensity laser therapy, HILT). During HILT, temperature in the treatment area rises, which increases the intensity of the metabolic process in cells

Address for correspondence:

Paulina Zielińska

Katedra i Klinika Chirurgii

Wydział Medycyny Weterynaryjnej

Uniwersytet Przyrodniczy we Wrocławiu

Plac Grunwaldzki 51, 50-366 Wrocław

Telephone: +48 536267722

E-mail: paulina.zielinska@up.wroc.pl

http://actavet.vfu.cz/ 
(Lukowicz et al. 2007). With the appropriate wavelength and high peak pulse power $(3 \mathrm{~kW})$, HILT allows for deeper tissue penetration and stimulation of body structures such as large and deep joints and extensive muscle parts (Zati and Valent 2006).

This article provides an overview of available publications concerning the scope and impact of low and high intensity laser therapies on the human and animal body.

\section{In vitro study and labolatory animal testing}

The positive effect of laser therapy on the organism observed in clinical trials gave rise to more detailed study of cells and tissue exposed to laser radiation. In vitro studies on fibroblasts and endothelial cells isolated from the skin and aorta of $\mathrm{C} 3 \mathrm{H}$ mice irradiated with red and infrared laser light have shown that the higher the wavelength of the red light, the more effective is the growth of fibroblasts. The optimal length for the endothelial cells was $655 \mathrm{~nm}$, and the wavelength of $810 \mathrm{~nm}$ inhibited growth of both endothelial cells and fibroblasts (Moore et al. 2005). Another study evaluated in vitro the effect of laser radiation on the acethylcholinesterase (AChE) activity in erythrocyte membranes. The red cells were exposed to laser radiation at a wavelength of $808 \mathrm{~nm}$ and $905 \mathrm{~nm}$ with variable parameters. Authors indicated that the laser biostimulation caused changes in AChE activity depending on the parameters used. The highest increase of AChE activity was obtained using laser light with the wavelength of $905 \mathrm{~nm}$ and $1,000 \mathrm{~Hz}$ or $2,000 \mathrm{~Hz}$ with the peak pulse power of 1,100 $\mathrm{mW}$ and energy dose of $3 \mathrm{~J}$ (Pasternak 2012). Renno et al. (2011) demonstrated a positive effect of laser radiation with a wavelength of $660 \mathrm{~nm}$ on the granulation and epidermisation of second-degree burn wounds in rats. Similar results were obtained by Voronkov et al. (2014), who exposed the surface of burn wounds in rabbits to red and near-infrared laser radiation and observed a significantly reduced infiltration of tissue with leukocytes, reduced swelling of the dermis and much more numerous and more organized collagen fibres than in the control group. Also Kovács (2015) in her studies observed a positive influence on deep, extended wound healing after LLLT treatment with a wavelength of $810 \mathrm{~nm}$ in 5 dogs. Laser radiation with wavelengths of $600 \mathrm{~nm}$ and $684 \mathrm{~nm}$ at $7.5 \mathrm{~J} / \mathrm{cm}^{2}$ of carrageenan-induced rat paw oedema effectively reduced the formation and size of the oedema and migration of inflammatory cells (Albertini et al. 2007). Laser photobiostimulation with a wavelength of $830 \mathrm{~nm}$ at $4 \mathrm{~J} / \mathrm{cm}^{2}$ of damaged tibialis anterior muscles in rabbits effectively reduced inflammation in the injured tissue, and significantly increased the level of myogenin in the treatment group compared to the control group (Pertille et al. 2012). Similar results were obtained by Rodrigues et al. (2013), who exposed damaged tibialis anterior muscles in rats with a wavelength of $660 \mathrm{~nm}$ at $10 \mathrm{~J} / \mathrm{cm}^{2}$ and $50 \mathrm{~J} / \mathrm{cm}^{2}$. Both Albertini et al. (2007) and Rodrigues et al. (2014) demonstrated that LLLT reduces immunoexpression of COX-2 in damaged muscles, thus decreasing the severity of inflammation and facilitating tissue repair processes. Tests were performed on the safety of high-intensity laser therapy in which $8 \mathrm{~cm}^{2}$ of the back of mice were irradiated twice a week for six months. Two wavelengths, $585 \mathrm{~nm}$ and $1320 \mathrm{~nm}$, were used at various energy doses ranging from 8 to $20 \mathrm{~J} / \mathrm{cm}^{2}$. Both during and after the test, there were no deaths, symptoms of intoxication, or neoplastic processes in any of the mice (Chan et al. 2007).

\section{Human medicine}

In human medicine, the biological effects of low-level laser therapy began to be investigated in the mid-1960s. As early as 1969, Dr. Endre Mester successfully used laser light to treat non-healing skin ulcers, and thus introduced lasers to medicine (Mester et al. 1985). Low-level laser therapy has found application in the treatment of hard-to-heal wounds and skin injuries (especially decubitus ulcers), chronic and subacute inflammation of soft tissue, oedema, calcaneal spurs and the carpal tunnel syndrome (Bauer et al. 2012). 
The possible applications of LLLT in human physiotherapy are well known. Current research on the future of laser treatment concerns class IV lasers. Irradiation of acne lesions of the head and neck with laser light of a wavelength of $970 \mathrm{~nm}$ at $10 \mathrm{~J} / \mathrm{cm}^{2}, 5 \mathrm{~W}$, and a variable frequency ranging from 10 to $1000 \mathrm{~Hz}$, led to the complete regression of the lesions after treatment (Gobbo et al. 2012). Alay at et al. (2014) evaluated the effectiveness of HILT in the treatment of chronic lower-back pain. The treatment group was subjected to the therapy $\times 3$ a week for four weeks. The treatment area included the lumbar spine and the first sacral vertebra. A placebo was used in the control group. Irradiation increased the mobility of intervertebral joints in the treatment group. However, there were no significant differences in the perception of pain by the patients of both groups. In 2014, Khesie et al. (2014) evaluated the impact of both low and high intensity laser therapies on patients diagnosed with knee osteoarthritis. A group of 53 men was divided into three groups: those exposed to class IV laser irradiation, those exposed to class IIIB laser irradiation, and a control group. The low and high intensity laser treatments significantly reduced pain perceived by patients as measured on the VAS scale, and improved the functionality of the knee joint and the general mobility of the knee joint in WOMAC scores. At the same time, it was found that the high intensity laser therapy was more effective than the low level laser therapy. Other studies on the use of HILT have concerned its impact on the treatment of shoulder joint pain in the impingement syndrome. Ten sessions of therapeutic radiation at a wavelength of $1,064 \mathrm{~nm}$ at $2,050 \mathrm{~J}$ and $6 \mathrm{~W}$ reduced joint pain, increased the range of motion, and improved the muscle strength of the shoulder (Santamato et al. 2009). An analysis of the impact of HILT on women with fibromyalgia showed that exposure of each tender point on the body to laser light of the two wavelengths of $810 \mathrm{~nm}$ and $980 \mathrm{~nm}$ at $600 \mathrm{~J}$ effectively reduced the pain felt by patients, positively affected the mobility of the upper part of the body, and reduced the overall physical discomfort (Panton et al. 2013). In a study on the influence of HILT on the process of bone healing in a radial bone fracture, a significant effect of HILT was found on the reducing of pain using assessment by both VAS scale and Leitinena scale. In contrast, assessing the concentrations of bone turnover markers (bone resorption marker serum type $1 \mathrm{C}$-telopeptides CTX, bone formation marker osteocalcin OC) before and 6 months after the last treatment did not confirm any effect on the bone regeneration process ( ukowicz et al. 2011).

\section{Equine veterinary medicine}

Laser therapy was introduced to equine veterinary medicine in 1980 and was used mainly to treat orthopaedic diseases (Henson 2009). Continuous exploration and development of methods for treating diseases and injures of the musculoskeletal system in horses has led to the increasing use of physiotherapy by veterinarians. In their study conducted in New Zealand, Meredith et al. (2001) found that physiotherapy was the second most common method of health promotion in sport horses, and used most often (in $36 \%$ of cases) in the jumping horses. The beneficial effect of LLLT on wound healing in horses was confirmed by Jann et al. (2012), who exposed a surgical skin wound of the dorsal surface of the metacarpal region to radiation. Laser radiation of a wavelength of $635 \mathrm{~nm}$ was applied at $5.1 \mathrm{~J} / \mathrm{cm}^{2}$ in eight mares. On the $17^{\text {th }}$ day of the therapy, there was a significant difference in the size of the wound between the control group and the treatment group. On the $80^{\text {th }}$ day, the wounds in the control group were $9 \%$ bigger than in the irradiated group, in which the wounds were closed and the process of epidermisation was completed. In a similar study, wounds made on the dorsal surface of the metacarpophalangeal joint were irradiated with a wavelength of $830 \mathrm{~nm}$ at $2 \mathrm{~J} / \mathrm{cm}^{2}$. After 30 days of treatment carried out at 24-h intervals, there were no significant differences in the healing of wounds and their size between the treatment group and the control group. However, it was noted that the wounds subjected to therapy were less swollen and produced less exudate, particularly in chestnut 
horses. Furthermore, the wounds of the horses in the treatment group were less sensitive to touch than those of the horses in the control group (Petersen et al. 1999). An in vivo study evaluated the depth of penetration of the laser beam in equine tendons. The study used a GaAlAs laser, which emitted a continuous laser beam of the wavelength of $810 \mathrm{~nm}$ at $500 \mathrm{~mW}$. To assess the penetration depth of the laser, a light-sensitive sensor with a wavelength ranging from 600 to $1300 \mathrm{~nm}$ was used. It was shown that the skin pigmentation in the treatment area did not affect the penetration depth of the laser light in the equine flexor tendons, and removing hair from the operative field and disinfecting the skin with alcohol significantly increased the penetration depth of laser radiation into the tissue (Ryan and Smith 2007). Bromiley (2000) also recommends shaving and disinfecting the treatment area before laser therapy. In a study on the effects of highintensity laser therapy on the healing process of damaged flexor tendons in horses, it was demonstrated that the application of a wavelength of $1,064 \mathrm{~nm}$ at $6 \mathrm{~W}$ and three energy levels significantly increased the number and activity of fibroblasts within the damaged area and stimulated the formation of new collagen fibres. An ultrasound image also showed a significant difference in the increase of echogenicity within the damaged area between the control group and the treatment group (Fortuna et al. 2002). Vallance et al. (2012) studied the induction of tendinopathy in the superficial digital flexor tendon using a diode laser with a wavelength of $980 \mathrm{~nm}$. The experiment was carried out in isolated tendons in a group of three horses. The researchers demonstrated a linear relationship between the amount of damage assessed by histology and the dose of radiation energy applied on the isolated damaged material, but they could not show such a relationship in in vivo studies. Some authors claim that HILT is a safe treatment method which is well tolerated by horses and does not require pharmacological sedation. Highly pigmented skin irradiation at the appropriate treatment parameters did not cause any excessive increase of temperature in superficial tissues (Fortuna et al. 2002; Zielińska et al. 2015).

In conclusion, it is difficult to clearly assess the effectiveness of laser therapy in the treatment of diseases in humans and horses. There are no standardized testing methods and parameters used in these procedures tend to differ with respect to wavelength, energy dose, and the number and frequency of treatments. Clearly, it appears that laser power and wavelength are critical to the depth of the tissue penetration of laser radiation (Ross and Dyson 2003). Interest in laser therapy is constantly growing among physiotherapists and veterinarians. This trend is associated mainly with the promising results found in investigations, the non-invasiveness and safety of the therapy, low treatment costs, and the simplicity of the technique. The introduction of laser therapy to veterinary medicine, particularly to analgesic therapy in horses, might improve the quality of life of patients with chronic pain, for example from osteoarthritis or damage within tendons and ligaments.

\section{References}

Alayat MSM, Atya AM, Ali MME, Shosha TM 2014: Long-term effect of high-intensity laser therapy in the treatment of patients with chronic low back pain: a randomized blinded placebo-controlled trial. Laser med sci 29: 1065-1073

Albertini R, Aimbire F, Villaverde AB, Silva JA, Costa MS 2007: COX-2 mRNA expression decreases in the subplantar muscle of rat paw subjected to carrageenan-induced inflammation after low level laser therapy. Inflamm Res 56: 228-229

Albertini R, Villaverde AB, Aimbire F, Salgado MAC, Biordal JM, Alves LP, Munin E, Costa MS 2007: Antiinflammatory effects of low-level laser therapy (LLLT) with two different red wavelengths (660 $\mathrm{nm}$ and $684 \mathrm{~nm}$ ) in carrageenan-induced rat paw edema. J Photoch Photobio B 89: 50-55

Bauer A, Wiecheć M, Śliwiński Z 2012: Methodical guide on the selected physical treatments (in Polish). Markmed Rehabilitacja s.c. III edition, Wrocław pp. 351-360

Bromiley M, 2007: Equine injury, therapy and rehabilitation. Blackwell publishing III edition, Oxford, pp. 109-115

Chan HHL, Yang CH, Leung JCK, Wei WI, Lai KN 2007: An animal study of the effects on p16 and PCNA 
expression of repeated treatment with high-energy laser and intense pulsed light exposure. Laser Sur Med 39: 8-13

Fiodor P, Kręcik T, Niechoda Z, Nowakowski W, Nowicki M, Otto W, Pirozyński M, Stanowski E 1995: Clinical aplications of laser therapy (in Polish). ANKAR, Warszawa

Fortuna D, Rossi G, Paolini C, Magi A, Losani F, Fallaci S, Pacini F, Porciani C, Sandler A, Torre RD, Pinna S, Venturini A 2002: Nd: YAG pulsed-wave laser as support therapy in the treatment of teno-desmopathies of athlete horses: a clinical and experimental trial. In Laser Florence 2001: A Window on the Laser Medicine World: International Society for Optics and Photonics 4903: 105-118

Glinkowski W, Pokora L 1995: Laser therapy (in Polish). Wydawnictwo Lekarskie PZWL, Warszawa, pp. 61-84

Gobbo M. Ottaviani G, Mustacchi G, Di Lenarda R, Biasotto M 2012: Acneiform rash due to epidermal growth factor receptor inhibitors: high-level laser therapy as an innovative approach. Laser Med Sci 27: 1085-1090

Henson FM 2009: Equine back pathology: diagnosis and treatment. John Wiley \& Sons, Hoboken, pp. 225-234

Jann HW, Bartels K, Ritchey JW, Payton M, Bennett JM 2012: Equine wound healing: influence of low level laser therapy on an equine metacarpal wound healing model. Photon Laser Med 1: 117-122

Khesie AR, Alayat MSM, Ali MME 2014: High-intensity versus low-level laser therapy in the treatment of patients with knee osteoarthritis: a randomized controlled trial. Laser Med Sci 29: 1371-1376

Kitchen SS, Partridge CJ 1991: A review of low level laser therapy: Part I: background, physiological effect and hazards. Physiotherapy 77: 161-168

Kovács K 2015: Low Level Laser Therapy of serious wounds of dogs. Lasers in Surgery and Medicine 47: Number S26

Łukowicz M, Pawlak A, Pawlikowski J, Weber-Zimmermann M, Zalewski P 2007: High-intensity laser therapy (HILT) - clinical applications (in Polish). Acta Bio-Optica et Informatica Medica 4: 326-330

Łukowicz M, Szymańska J, Skopowska A, Weber-Rajek M, Ciechanowska-Mendyk K, Buszko K 2011: The influence of High Intensity Laser Therapy on bone regeneration (in Polish). Acta Bio-Optica et Informatica Medica 17: 99-102

Mikołajewska E 2011: Outline of physiotherapy. Physiotherapy for practicioners (in Polish). Wydawnictwo Lekarskie PZWL, Warszawa, pp. 94-109

Meredith K, Bolwel CF, Rogers CW, Gee EK 2001: The use of allied health therapies on competition horses in the North Island of New Zealand. New Zeal Vet J 59: 123-127

Mester E, Mester AF, Mester A 1985: The biomedical effects of laser application. Lasers in surgery and medicine 5: $31-39$

Moore P, Ridgway TD, Higbee RG, Howard EW, Lucroy MD 2005: Effect of wavelength of low-intensity laser irradiation-stimulated cell proliferation in vitro. Laser Sur Med 36: 8-12

Panton L, Simonavice E, Williams K, Mojock C, Kim JS, Kingsley JD, McMilan V, Mathis R 2013: Effects of Class IV laser therapy on fibromyalgia impact and function in women with fibromyalgia. J Altern Complem Med 19: 445-452

Pasternak K, Szrajber B, Kujawa J 2012: Effect of MLS laser radiation on acetylcholinesterase activity in erythrocyte membranes. Kwart Ortop 4: 469-478

Pertille A, Madeco AB, Oliveira CP 2012: Evaluation of muscle regeneration in aged animals after treatment with low-level laser therapy. Braz J Phys Ther 16: 495-501

Petersen SL, Botes C, Olivier A, Guthrie AJ 1999: The effect of low level laser therapy (LLLT) on wound healing in horses. Equine Vet J 31: 228-231

Renno ACM, Iwama AM, Shima P, Fernandes KR, Carvalho JG, De Oliveira P, Ribeiro DA 2011: Effect of low-level laser therapy $(660 \mathrm{~nm})$ on the healing of second-degree skin burns in rat. J Cosmet Laser Ther 13: $237-242$

Riegel R, Sepion L 2007: Laser therapy for the equine athlete. LiteCure LLC, Newark, pp. 7-71

Rodrigues NC, Assis L, Fernander KR, Magri A, Ribeiro DA, Brunelli R, Abreu DCC, Renno ACM 2013: Effect of $660 \mathrm{~nm}$ low-level laser therapy on muscle healing process after cryolesion. J Rehabil Des Dev 50: $985-996$

Rodrigues NC, Brunelli R, Abreu DCC, Fernandes K, Parizotto NA, Renno ACM 2014: Morphological aspects and Cox-2 expression after exposure to 780-nm laser therapy in injured skeletal muscle: an in vivo study. Braz J Phys Ther 18: 395-401

Ross MW, Dyson SJ 2003: Diagnosis and Management of Lameness in the Horse. Elsevier Health Sciences, St. Louis, pp. 811-814

Ryan T, Smith RKW 2007: An investigation into the depth of penetration of low level laser therapy through the equine tendon in vivo. Irish Vet J 60: 295-299

Santamato A, Solfrizzi V, Panza F, Tondi G, Frisardi V, Leggin BG, Ranieri M, Fiore P 2009: Short-term effects of high-intensity laser therapy versus ultrasound therapy in the treatment of people with subacromial impingement syndrome: a randomized clinical trial. Phys Ther 89: 643-652

Ward A, Robertson V, Low J, Reed A 2009: Physiotherapy. Clinical and biophysical aspects (in Polish). Edra Urban \& Partner I edition, Wrocław

Vallance SA, Vidal MA, Whitcomb MB, Murphy BG, Spriet M, Galuppo LD 2012: Evaluation of a diode laser for use in induction of tendinopathy in the superficial digital flexor tendon of horses. Am J Vet Res 73: 1435-1444

Voronkov MG, Matorina IG, Iushkov GG, Benemanski VV, Rasulov MM, Snisarenko TA, Abzaeva KA, Shukina 
OG, Malishakina NA 2014: Effect of laser radiation of infrared and red range of healing of burn wounds. Dokl Bioch Biophys 456: 85-87

Zati A, Valent A 2006: Physical therapy: new technologies in rehabilitation medicine. Edizioni Minerva Medica 162-185

Zielińska P, Kiełbowicz Z, Paczuska J 2015: High Intensity Laser Therapy (HILT) in the treatment of orthopedic diseases in horses (in Polish). Med Weter 6: 373-377 